\title{
Traditional Rulers and Local Government in Nigeria: a Pathway to Resolving the Challenge
}

\section{Daniel Adetoritse Tonwe}

Department of Political Science \& Public Administration, University of Benin, Nigeria

Email: datonwe@yahoo.com

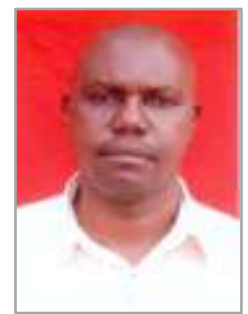

\section{Osa Osemwota}

Institute of Public Administration \& Extension Services, University of Benin, Nigeria.

Email: osaosemwota@yahoo.com

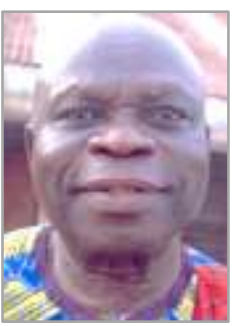

\begin{abstract}
Abtract
This paper examines the problem of integrating traditional rulers into the contemporary local government system in Nigeria with a view of resolving the problems arising from the tradition/modernity nexus in the present scheme. Two basic questions guided this work. The first relates to the relevance of indigenous traditional institutions to the challenges of contemporary democratic processes. The second relates to whether traditional modes of thought, behaviour and institutions constitute resources or impediments to the projects of modernisation and development. This paper concludes that the goal of modernisation is to generate rapid increase in social wealth and its driving force is economic development; and where traditional institutions are able to contribute positively to this goal, their input should not be jettisoned.
\end{abstract}

Key words: traditional authority systems, traditional rulers (Emirs, Obas), cultural revivalism, antimodern.

\section{Introduction}

For centuries before the advent of British rule, governance in different parts of present-day Nigeria was synonymous with traditional institutions and their rulers. Local administration generally centered on the traditional ruler who was considered the repository of religious, legislative, executive and judicial functions, with a few exceptions (e.g.: in the south-east amongst Ibo communities) (Afigbo 1972). In effect, the traditional ruler formed the nucleus of governance. One striking fact is that the geographical spheres of authority of these traditional rulers were essentially localised and no traditional ruler ever had jurisdiction over the entire geographical area of modern Nigeria. Partly on account of this historical background, the tendency has been to view and analyse the developments taking place in traditional institutions in the country more in relation to local government as opposed 
to the country's governmental system at large. The role of traditional rulers in local government administration has been changing over the years. From a position where they were chief executives of their localities, they now serve as advisers in the contemporary local government system. This has created a problem in the relationship between traditional rulers and elected local government actors. The focus of this paper is to examine the problem of integrating traditional rulers into the contemporary local government system in Nigeria and discern a pathway to resolving the challenge.

This paper is based on secondary data and relied on national and international literature, and review of relevant legislation and constitutional provisions. The paper is structured into six sections. The first section introduces the subject of traditional authorities. The second examines various perspectives on the relevance of indigenous African traditional institutions in the context of the challenges of contemporary democratic process. The third section traces the contours of the changing role of traditional rulers in local government in Nigeria. The fourth section examines the emergent local government system in Nigeria and the problems of harmonious co-existence between traditional authorities and elected local government actors. The final sections explore options for resolving the tradition/modernity nexus in Nigeria are addresses in the fifth section, and draw conclusions from the analysis.

\section{Laying out the turf}

The nexus between the traditional and modern has been a central theme of postcolonial African philosophy. African philosophers have examined this theme from many angles, yet two questions have become the focus of ongoing debate. The first relates to the relevance of indigenous African traditional institutions to the challenges of contemporary democratic process. The question relates to whether traditional modes of thought, behaviour, and institutions constitute resources or impediments to development and modernisation in Africa (Ciaffa 2008).

The discussion of such questions reveals a conflict between two broad perspectives. The first perspective relates to cultural revivalism. This perspective assumes a reverential attitude toward African cultural heritage. In Gyekye's view, the key to addressing contemporary problems effectively lies in reclaiming and revitalizing indigenous traditions that have been degraded and suppressed in the wake of colonialism (Gyekye 1997:233). He argued that colonialism violently disrupted African cultural traditions and imposed, with varying degrees of success, European forms of thought and social organisation on colonised peoples. Having achieved political independence, postcolonial Africans must now pursue a more decisive liberation, a decolonisation of African minds and societies. Revivalists are often skeptical of calls for development and modernisation, viewing them as veiled calls for the continued imposition of European cultural norms, but it is important to realize that they do not typically view their own project as anti-modern. For revivalists, the key point is that genuine modernisation in Africa can only be realised through the revitalisation of African cultural norms. 
The second perspective is predicated on the assumption that the revivalist project is misguided and illsuited to the challenges of contemporary Africa. Proponents of this school of thought argue that cultural revivalism diverts attention from pressing political issues, such as authoritarian oppression, technological backwardness and class exploitation (Eze 1997). The most extreme form of this view, suggests that Africans must make a clean break with the pre-modern past in order to address the most urgent demands of the present (Hountondji, 1996:48). Modernisation, for them, requires a orientation commensurate with the problems of the present, and not an attempt to resurrect ideas from societies of the distant past.

Basically, modernisation is a sign of progress and an ideal to be pursued. In examining the debate between cultural revivalism and its critics, the key question is: do indigenous traditions and traditional institutions enhance or impede the processes of scientific and political modernisation? It is from this context that this paper examines the role of traditional authorities in the contemporary local government system in Nigeria.

\section{Traditional authority systems and traditional rulers in Nigeria}

It is difficult to provide a universally accepted definition of a traditional system of authority in Nigeria because of the diversity in the political and administrative components of traditional systems in different parts of the country. This difficulty notwithstanding, traditional systems of authority may be defined as the indigenous polity which existed before the advent of the colonialists (Adewumi \& Egwurube 1985:20).

The responsibility for giving appropriate definition as to who is a traditional ruler is primarily that of the State Governments. There are no fundamental variations in the definitions contained in the Traditional Rulers and Chiefs Law of the various State Governments (Onoja 2007; Emordi \& Osiki 2008). Based on the review of various of State laws, Ola and Tonwe (2009:174) argue that a 'traditional ruler' may be defined as 'the traditional head of an ethnic group or clan who is the holder of the highest primary executive authority in an indigenous polity, or who has been appointed to the positioning accordance with the customs and tradition of the area concerned by instrument or order of the state government, and whose title is recognised as a traditional ruler title by the Government of the State'.

\section{Traditional rulers and local government in Nigeria: changing roles}

The role of traditional rulers in relation to local government has been changing over the years. In tracing the contours of the role of traditional rulers in local government in Nigeria, three distinct geographical regions are discernible, the north, the south-west and the south-east. 
In the pre-colonial era, a close examination of the established traditional institutions and their rulers reveals that in the task of governance, the traditional rulers had to shape appropriate policies, order priorities and generate revenue to meet the needs of their communities in the exercise of these functions. In the North, the Emir could be referred to as a strong executive participator in local administration with few restraints on his executive powers. In the South-West, beside the Oba (or king), there were other power blocks or centers such as the body of king makers, the town council and powerful secret societies whose input in shaping the local administration acted as checks on the Oba's power, so the Oba can be regarded as a weak executive participator in local administration (Oguntomisin 1996). In the South-East, the indigenous political system reveals a great deal of popular participation and was highly decentralised and fragmented with authority being exercised at different levels, from the household level to the village level with an absence of centralised executive authority. In all, the traditional ruler was an embodiment of local administration (Ola \& Tonwe 2009).

With the advent of colonialism, the British colonial administrators recognised the strategic and influential position occupied by traditional rulers in the country. The colonial administrators had a number of problems, including limited British personnel, and limited finance to run the country, as British colonial policy was to generate cost of running colonies and managing the volatile law and order situations from the colonies themselves. Largely for these reasons, the colonialists avoided attempting any drastic reforms of the indigenous local administration (Adesoji 2010). Instead, the British colonial administration took steps to put in place a system of indirect rule, as a convenient strategy to govern the people through their traditional institutions and rulers while ensuring close guidance by British Administrators. In this way, the allegiance of the people was secured via their traditional rulers (Ola 1983:24). In effect, there was a clear attempt by the colonial government to consolidate the role of traditional rulers as chief executives of their localities, and this was extended to areas where traditional rulers had not hitherto held this power.

One of the features of indirect rule and native authority system was that nationalists were not encouraged to serve in the local councils. The traditional rulers were in firm control of their local councils and they tended to be despotic and authoritarian in performing their functions which were essentially maintenance of law and order, and enforcement of tax policies of the British colonial government. By mid-1940s however, political parties in the country had begun to assert themselves. Nationalists were forceful in demanding adequate representation in government affairs, while at the same time pressing for self-rule. They contended that the existing Native Authority System was incompatible with modern secular and democratic tenets of local government. About this time too, the British government was re-appraising its strategy of governance at the local level with the aim of evolving a system of democratic and efficient local government. An official report, presented to the British Parliament in July 1949, stated that the objective of the new system was the encouragement of local political interest and building of efficient and democratic local government as a cardinal feature 
of the British policy in Africa (Uchendu 1965). It was recognised that political progress of the territories was dependent on the development of responsible local government, that without sound local government a democratic political system at the center was not possible, and that if social services were to be expanded they must be operated by an efficient organ of local government directly representative of the people (Orewa \& Adewumi 1983).

The South-East of the country presented the most fertile ground to implement the British Government's new policy as the traditional societal setting was highly atomised, and there were few despotic or authoritarian traditional rulers. The Eastern Region took the historic step of abolishing the Native Authority System and replacing it with the Local Government Ordinance, 1950. The Ordinance provided for largely elected councils, with non-elected members not expected to exceed 25\%. The Chairmen of the councils were to be elected from amongst the elected councilors (Orewa and Adewumi 1983).

In the Western Region, the Western Region Local Government Law 1952 was promulgated to replace the old Native Authority System. The law provided for local councils to consist of both elected and traditional members, with traditional membership not exceeding a quarter of its total membership. The law further provides that, recognised chiefs (i.e.: traditional rulers) could be appointed president of the councils, but did not assign them any specific role, and as such they were ceremonial presidents. To further ensure that traditional rulers were excluded from active participation in local government, the Local Government Law was amended so that no traditional ruler appointed as president of the council could also be appointed chairman of the council (Atanda 1970).

In the Northern Region, the old Native Authority Ordinance was replaced by the Native Authority Law 1954. The law provided for a number of operational frameworks including Chief-in-Council, Chief-and-Council and Federated Native Authorities. In the Chief-in-Council arrangement, the Emir had the power to veto council decisions, provided that he informed the governor whenever he did so. In the Chief-and-Council arrangement, the law provided that the Emir could not act contrary to the decision of the Council. However, because in the Northern Region, Islam has been established so long and so firmly that its practice has become inter-twined with those of traditional political authority - a type of Theocracy; it was difficult to discern any difference in power of the Emirs between the Chiefin-Council and Chief-and-Council arrangements. Federated Native Authorities were also set up to cater for communities not directly under the Emirates. In many cases, dissimilar communities in terms of history and tradition were grouped together under this arrangement, coupled with shaky headship arrangement, the internal harmony and effectiveness of most of the Federated Native Authorities left much to be desired (Ekong 1985).

The emphasis of the 1950s was the democratisation of the local government system in the country, and the historical climb-down meant that, for traditional authorities in the South-East and South-West 
of the country, democratisation meant the loss of their executive role for a participatory role in the affairs of local government. The extent to which traditional rulers were involved in the decision making process at the local level during this period depended on how much influence individual traditional rulers wielded in the eyes of the political actors at this level. In the North, the introduction of the Chief-in-Council and Chief-and-Council did not succeed in taking away the executive powers of the Emirs, who still local executive functions (Last 1999).

Before Nigeria gained independence in 1960, the contention by a cross-section of nationalists that the institution of traditional rulership was in direct conflict with democratic ideals as the system was personalised had gained considerable momentum. After independence, the political elites continued to try to reduce the influence of traditional rulers in local decision-making. From 1960 to 1966, when the military seized power, the democratisation effort in Eastern and Western Regions had a significant adverse effect on influence of traditional rulers in local decision-making. In most parts of the Northern Region, however, the Emirs were still in control of their Councils as the democratisation effort appeared to be neutralised by their overwhelming influence. By January 15, 1966 when the military seized power, the extent of influence of traditional rulers was greatly influenced by which side of the political fence they faced (Orewa \& Adewumi 1983).

The assumption of political power by the military in 1966 had substantial implications for to role of traditional rulers in local government. In the Northern States between 1966 and 1972 Customary/Native Courts were taken over by state governments, and Prisons and Police were taken over by the Federal Government. The nomenclature of Native Authority was dropped and the existing Native Authorities balkanised into independent local government units, but the Emirs were still influential in the decision-making process at the local level. New provisions were introduced for election of two-thirds of the membership of the Local Government Councils. In Western states (including the Mid-west), before 1966, the role of traditional rulers in local government had been essentially ceremonial. The situation was the same in parts of the Eastern States where traditional rulership still existed (Ola \& Tonwe 2009).

At the terminal phase of the Mohammed/Obasanjo military regime which ended in 1979, the Federal Military Government in consultation with State Governments attempted to institute a uniform role for traditional rulers throughout the country through the 1976 Local Government Reform. Traditional rulers were insulated from politics and formally assigned advisory roles in local decision-making through Traditional/Emirate Councils (GLGR 1976). The advice of the traditional rulers is not binding on the elected local government councilors.

The strongest opposition to these reforms came from the traditional rulers in the Northern Nigera, where traditional rulers still played a significant role in the decision making process at the local level, so the effect of the uniform advisory role was obviously more significant. For the traditional rulers in 
the South-West and South-East of the country, their being assigned advisory role by the 1976 Reform was only stating in 'black and white' what had been their role for well over a decade (Uchendu 1965). Thus, it appears that the problem of traditional rulers is more of a Northern problem where the existence of dual authority structure, the traditional and the secular is very pronounced. In the country at large, however, the crux of the problem lies with the degree of decision-making prominence which the government gives to dynastic traditional rulers in the context of a gradually evolving local government system directed at popular representation, citizen participation and mobilisation, and their role as informed observers and ceremonial participants in matters of local government (Adewumi \& Egwurube 1985:31).

After the inception of the 1979 Constitution, traditional rulers were very critical that the constitution did not mention their role in local government. Traditional rulers, particularly those in the North, were far from being contented with the advisory/ceremonial role assigned to them. The degree of prominence in local decision-making that traditional rulers could be given by democratically elected local government councils guaranteed by the Constitution was the subject of heated debates during the Second Republic from 1979-1983 (Gboyega 1987). These debates did not quite concretise before the military seized power again in December, 1983.

Perhaps in response to the call by traditional rulers for constitutional recognition of their role in local government, the 1989 Constitution spelt out the functions of a Traditional Council at local government level. Critically speaking, this development cannot be regarded as an enhancement of their role in local government affairs, as the 1999 Constitution does not specify the functions of traditional authorities. The on-going effort of the Nigerian Senate to fashion a constitutional role for traditional rulers in is timely and in the right direction (Vanguard 2012:13).

\section{Emergent local government system: persistence of co-existence}

Having catalogued the historical antecedents that frame the present status of traditional rulers in the country, the next important area of examination is the extent to which traditional authorities and local governments co-exist in contemporary Nigerian local government.

Under the 1999 Constitution, it is obvious that local governments should play a leading role in the emergent order, as traditional rulers are still vital to the attainment of economic progress and political stability at the local level. The continued relevance of traditional authorities to the local government system in contemporary Nigeria as Egwurube (1985:34) rightly noted may be attributed to the following reasons. First, participant political culture among the majority the citizens, especially in rural areas is still dormant. Second, traditional authorities are still legitimate in the eyes many people. Third, attempts to institutionalise alternative local leadership structures in modern, stable and elected local government institutions, that would eventually receive the overall acceptance of the citizenry, 
have largely failed. Thus institutions which essentially have a local base must complement the efforts of each other for effective governance at the local level.

To ensure that this is achieved, efforts have been made to state the working relationship between traditional authorities and local government in the country. In spite of this, there are frictions, and the peaceful co-existence between both institutions is very much in doubt. Two major reasons are given. First, traditional rulers, especially those who were very powerful in the past, are disillusioned with the present political arrangement, which assigns them only nominal advisory roles in local government affairs. A number of traditional rulers have expressed their concern in seminars and conferences on traditional authorities and local government relations. Prominent traditional rulers such as the Oba of Benin and the Alafin of Oyo have vehemently expressed their dissatisfaction with how traditional institutions and their rulers have been relegated to the background over the years (Amadi 2007).

Unsurprisingly, concerted efforts by traditional rulers to enhance their role in the local government and macro-political affairs have pre-occupied them more than anything else. This posture has greatly affected their interest in and contribution to the effectiveness of local government under the present dispensation.

Second, there is a great deal of insensitivity amongst modern elected local government councillors to the ego of tradition rulers. Even though they are assigned advisory roles, relevant provisions are not fully respected. Legislation in the former Bendel Sate (now transferred to the replacement Edo and Delta States) specifies the role of traditional councils at local government level - Section 47 of Part VIII of the Traditional Rulers and Chiefs Edict, 1979 specifies the following functions:

a) Formulation of general proposals by way of advice to the Local Government or to all local governments in the area.

b) Harmonisation and co-ordination of development plans of such local governments by joint discussions and advice.

c) To assist in the maintenance of law and order (Bendel State of Nigeria, 1979).

Under the same Edict, the Secretary to the local government is also required to furnish the President of the Traditional Council with copies of all meeting minutes of the Local Government Council, copies of all agendas, memoranda and other documents and information as would enable the President to be fully conversant with proceedings of the Local Government Councils. The President also has the privilege of inspecting all books, including minute books of the Local Government Council or Councils where there are two or more local government councils under his jurisdiction, to enable him obtain sufficient information for full discharge of the functions conferred on him under the Edict.

The traditional rulers have complained on many occasions that, because the role envisaged for them under the Edict is advisory, local government administrators see the implementation of these 
provisions as inconsequential and an unnecessary burden. This situation has further alienated traditional rulers from the activities of local governments, with varying results. Some traditional rulers have cited shabby treatment by elected local government functionaries as justification for their lukewarm attitude in performing their advisory role in their local government areas (Amadi 2007). In addition, modern local government actors themselves seem to portray any role of traditional rulers in governance as an unnecessary burden. This is all the more disturbing as a huge amount of public money is spent by state and local governments on the Traditional Councils all over the country. As much as five percent $(5 \%)$ of the statutory revenue of local government areas are mandatorily required to be remitted to traditional councils for their upkeep. This guaranteed source of funding of traditional authorities was put in place when the military regime under Sani Abachi decreed it in 1995 (Aiyede 2003; Akinwalere 2003:31).

\section{Resolving the tradition/modernity nexus}

In the pre-colonial era, as well as substantial part of the colonial era, traditional authorities played a significant and active role in the governance and development of local government, yet today the very essence of the institution is being questioned. The issue of relevance of traditional authorities in the country's modernizing polity is a highly controversial one, as there are divergent opinions and interest. Egwurube (1985) identifies three schools of thought in this regard.

One school contends that the institution of traditional rulership should be abolished, as it is an anachronism in a democratically elected local government system, guaranteed under Section 7(1) of the 1979, 1989 and 1999 Constitutions, and the parallel institution of traditional rulership is anomalous. While one envisages a competitive and participatory process, the other is a system based on authoritarian, personalised tradition. The supporters of this school conclude that, if the country is serious about ensuring that the citizenry adopts the democratic and participatory culture needed to quicken the pace of modernisation, then a decisive step needs to be taken to 'jettison this archaic institution once and for all' to enable the people develop the required orientation in line with the reality of the present age and time (Ayeni 1985).

The abolitionists have a point in that the principles behind democratic local government and the institution of traditional rulership are opposed to each other; the solution advanced by them does not appear realistic. For one thing, the high degree of acceptance of traditional authorities particularly in the rural areas cannot be dismissed as inconsequential, nor would be abolition of the institution of traditional rulership easily obliterate rulers' legitimacy and public acceptance. The abolitionist solution is confrontational and can create chaos in local government operations (Egwurube, 1985: 38).

Perhaps sometimes in the distant future when the polity is fully modernised, there may be no need for the institution of traditional rulership. However, at this modernizing stage, it is desirable to handle the 
issues relating to traditional authorities with caution and tact, if the objective of achieving a democratic, stable and durable local government system is to be achieved.

A second school of thought argues for political enhancement, contending that traditional rulers should be allowed to participate in politics to enhance their political position in the present system, envisaging a situation where traditional rulers make an effective contribution to local politics.

The adoption of this strategy is bound to be clouded with a number of difficulties. Section 7(1) of both the 1979, 1989 and 1999 Constitutions guaranteed a system of local government by democratically elected local government councils and as such does not envisage any active role for personalised institutions in the operation of local government. Part II of the Fourth Schedule of the 1989 Constitution (the 1999 Constitution has no provisions in this regard) set out the functions of a Traditional Council at the local government level. The second clause the Schedule clearly states that 'nothing in the schedule shall be construed as conferring any executive, legislative and judicial powers on a Traditional Council'. The chances that the Constitution will be amended to reflect the political enhancement solution are very slim. The high degree of legitimacy traditional rulers enjoy in the eyes of the citizenry is based on the belief that the institution of traditional rulership is a sacred one. Subjecting traditional authorities to rigors of the electoral process and petty politics society would make them a target of public scrutiny, and would destroy their sacredness thereby destroying their major source of strength. While the intention is to carve out a prominent role in local governance for traditional authorities, their strategy may in fact lead to the collapse of the institution of traditional rulership in the country (Egwurube 1985).

The middle-path in the continuum between the abolitionists and the political enhancers is the retentionist school of thought, which favours retention of the traditional authorities as participatory local government actors in advisory and non-executive capacities. The adoption of the retentionist strategy as Egwurube (1985: 35) rightly observed would not only ensure stability and continuity of emergent local government system based on democratic and participatory principles, but would also tap the strength of traditional authorities in the sphere of citizen mobilisation and acceptance of local government policies. This involvement of traditional rulers in local government affairs, in addition to their other ceremonial functions, would reduce potential acrimonies and confrontation between local government actors and traditional authorities. While the retentionist strategy may well serve the need of the present time, the future of traditional rulership would depend on its adaptability to its evolving setting and how ingeniously it modernised to maintain the balance between reconciliation with modernity and obliteration of tradition (Ayeni 1985: xxxviii).

Some developing countries have adopted the radical policy alternative of abolition. In Africa for example, outright legal abolition of traditional authorities has been pursued by Guinea in 1957, Burundi in 1960, Mali in 1961, Rwanda in 1962 and Zaire in 1973 (Bamidele 1985:32). In India, 
after initially opting for the retentionist policy, abolished the Zamindari (Feudal) institutions through the Land Reform Policy, and later through the Constitution of India, $26^{\text {th }}$ Amendment Act, 1971. In all these countries, what is evident is that the system got smashed, but not wiped out. The splintered particles of the smashed system still float in the macro and micro political processes. The experience shows that even in a delegitimised state, traditional systems of governance have proved to be a force at different levels of the polity. Outwardly exhibiting democratic pretentions, such dual systems continue to display feudal orientations and exploit traditional bases for leadership in various aspects of social life, but their activisms have had adverse implications for the growth of genuine democracy as well as political modernisation.

Other countries have adopted a more accommodating retentionist approach, perhaps realizing the futility of the abolitionist strategy, such as Senegal in 1960, Upper Volta in 1964, the Central African Republic in 1959, Cameroon in 1959 and 1966, and Congo-Brazzaville in 1967 which have attempted to adapt traditional institutions to their contemporary political and administrative framework (Dave 1989),. Nigeria should adopt the mellowed retentionist policy in the face of the radical abolitionist measures taken in the countries listed above. Instead of allowing traditional functionaries to exercise corrosive influence clandestinely, it is better to clothe them formally with legitimacy. While disallowing their active involvement in party politics, they can serve as agents of transition from traditionalism to modernism (Gyekye 1987).

\section{Conclusion}

The relevance of traditional institutions to the transformation of African economies and governance systems is highly disputed in the post-colonial literature. This study does not subscribe to the school of thought that hold, the view that the traditional system is anachronistic, undemocratic, divisive and costly; and as such a hindrance to the development and transformation of the continent. It is sad that, while some scholars are quick to comment that traditional rulers were adaptive enough to be used by both the colonial and post-colonial State, these scholars are unreceptive to the fact that traditional rulers can be adaptive in providing their services to a democratic State as catalysts for development.

In Nigeria, traditional rulers still record a high degree of legitimacy in the eyes of the people. There remains the need integrate the institution into the country's contemporary local government system. Political and economic development would be more successful when rooted in widely shared institutions and cultural values which traditional authorities represent. Traditional institutions constitute crucial resources that have the potential to promote grassroots governance and to facilitate access of rural communities to public services. The goal of modernisation is to generate a rapid increase in social wealth and its driving force is economic development. Traditional rulers in Nigeria are in a privileged position to contribute to this goal, and as such should not be jettisoned. 


\section{References}

Adesoji, A.O. (2010) Traditional Ruler Ship and Modern Governance in 20th Century. In Babawale, T.A. Alao and A. Adesoji (Eds.), The Chieftaincy Institution in Nigeria, Lagos: Concept Publishers for Centre for Black and African Arts and Civilisation.

Adewumi, J.B. \& Egwurube, J. (1985) The Roles of Traditional Rulers in Local Government: Historical Perspective in Aborisade O. (Ed.) Local Government and Traditional Rulers in Nigeria. Ile-Ife: Unife Press.

Afigbo, A.E. (1972) The Warrant Chiefs. London: Longman.

Aiyede, R. (2003). The dynamics of civil society and the democratisation process in Nigeria, Canadian Journal of African Studies, 37 (1) 8-20.

Akinwalere, D. (2003) Why Local Governments Must Be Retained. Lagos: Vanguard Newspapers, November 10 .

Amadi, E.O. (2007) Traditional Rulers Bare their Minds on Increasing Strained Relations with Elected Local Government Functionaries, This Day Newspapers, October 10.

Atanda, J.A. (1970) The Changing Status of the Alaafin of Oyo under Colonial Rule and Independence. In Crowder, M. and O. Ikime (Eds.), West African Chiefs: Their Changing Status under Colonial Rule and Independence, Ile-Ife: University of Ife Press. pp: 17-19.

Ayeni, C. (1985) The Traditional Authority System in Nigeria: Issues, Perspectives and Challenges, Lagos: Pinnacle Press.

Bendel State of Nigeria (1979) Traditional Rulers and Chiefs Edict. Benin City: Government Printers.

Ciaffa J.A. (2008) Tradition and Modernity in Post-Colonial African Philosophy. Humanitas, 1 (2) 22-29.

Constitution of India (1971) $26^{\text {th }}$ Amendment Act, New Delhi: Government of India Publication.

Dave, S.L. (1988) Abolition of Privy Purses in India: Lessons for Developing African States, Post-Graduate Roundtable, Department of Public Administration, Nagpur University. Nagpur.

Egwurube, J. (1985) Traditional Rulers and Local Government under the 1979 Nigeria Constitution. In Aborisade, O. (Ed.) Local Government and Traditional Rulers in Nigeria. Ile-Ife: Unife Press.

Ekong, E.E. (1985) Traditional Rulership in Contemporary Nigeria. In Aborisade, O. (Ed.): Local Government and Traditional Rulers in Nigeria, Ile-Ife: Unife Press.

Emordi, E.C. and O.M. Osiki, (2010) Traditional Rulers under Military Rule in Nigeria, 1966-1999. In Babawale, T.A. Alao and A. Adesoji (Eds.), The Chieftaincy Institution in Nigeria, Lagos: Concept Publishers for Centre for Black and African Arts and Civilisation. Pp. 481-497.

Eze, E. (1997), Response to Wiredu in Postcolonial African Philosophy. Cambridge: Blackwell.

Federal Republic of Nigeria. 1979 Constitution. Lagos: Federal Government Printers.

Federal Republic of Nigeria. 1989 Constitution. Lagos: Federal Government Printers.

Federal Republic of Nigeria. 1999 .Constitution. Lagos: Federal Government Printers.

Federal Republic of Nigeria 1976 Guidelines for Local Government Reform (GLGR), Lagos: Federal Government Press.

Gboyega, A. (1987) Political Values and Local Government in Nigeria. Lagos: Malthouse Publishing Ltd.

Gyekye, K. (1987) An Essay on African Philosophical Thought. Cambridge: Cambridge University Press.

Gyekye, K. (1997) Tradition and Modernity. New York: Oxford University Press.

Hountondji, P. (1996) African Philosophy: Myth and Reality. $2^{\text {nd }}$ ed. Bloomington: Indiana University Press.

Last. M. 1999. An Aristocracy in Political Crisis: The End of Indirect Rule and the Emergence of Party Politics in the Emirates of Northern Nigeria, The Journal of African History, 40(1) 147-148.

Oguntomisin G. O. (1996) The Yoruba Kingdoms. In Elaigwu J.I. and Erim E.O. (Ed.). Foundation of Nigerian Federalism (Pre-colonial Antecedent). Ile-Ife: University of Ife Press.

Ola, R.F. \& Tonwe, D.A. (2009). Local Adminitration and Local Government in Nigeria. Lagos: Amfitop Books. 
Ola, R.F. (1983). Local Administration in Nigeria. London: Kegan Paul International.

Onoja, A., 2007. Redefining Tradition: The Chieftaincy Institution in Nigeria. Ife Journal of History. 4(2) 227243.

Orewa, G.O. \& Adewumi, J.B. (1983) Local Government in Nigeria: The Changing Scene, Ethiope Publishing Corporation, Benin City.

Uchendu, V. C. (1965) The Igbo of South-east Nigeria, New York: Holt, Rinehart and Winston.

Vanguard Newspapers (2012) Senate to Fashion Constitutional Role for Traditional Rulers in Nigeria. December 12, p.13. 